\title{
Correlation of the in vivo Action of Streptomycin on Survival and on Protein Synthesis by Mycobacterium fortuitum
}

\author{
By C. HURWITZ, H. W. DOPPEL AND C. L. ROSANO \\ General Medical Research Service, VA Hospital; and Department of Microbiology, \\ Albany Medical College, Albany, New York
}

(Received 6 December 1963)

\begin{abstract}
SUMMARY
When a sensitive population of Mycobacterium fortuitum is exposed to streptomycin, two effects of the drug on viability can be experimentally differentiated: (1) a sublethal injury from which the cells recover once streptomycin is removed, and (2) a lethal injury from which no recovery occurs. Protein synthesis is markedly inhibited by streptomycin before sublethal or lethal effects on viability are noted. The effect on protein synthesis of exposure to streptomycin cannot be reversed by washing the cells by centrifugation, but protein synthesis recovers its original rate on further incubation after streptomycin is removed. It is postulated that streptomycin causes both sublethal and lethal injury to cells by irreversibly blocking protein synthesis, possibly by inactivating ribosomes.
\end{abstract}

\section{INTRODUCTION}

It has been suggested (Hurwitz \& Rosano, 1962) that exposure of sensitive cells to streptomycin may result in two categories of reactions: (1) primary reactions preceding or accompanying the loss of viability of the cell, and (2) secondary reactions following the death of the cell and possibly having no relation to the lethal effect of the drug. Many of the reactions which have been shown to occur after exposure of sensitive cells to streptomycin may fall into the second category. A comparison of the kinetics of the proposed lethal reactions with the kinetics of the effects of the drug on growth and on survival should help resolve these two types of reaction.

Evidence has been presented supporting the hypothesis that streptomycin exerts its lethal action on sensitive cells by blocking a late stage of protein biosynthesis. Erdös \& Ullmann (1959) reported that streptomycin blocked the reactions concerned with the transfer of amino acids from aminoacyl ribonucleic acid(RNA) to ribosomes. Spotts \& Stanier (1961) later proposed that streptomycin might interfere with the attachment of messenger RNA to ribosomes in sensitive cells. Flaks, Cox \& White (1962) showed that the antibiotic inhibited the polyuridylic acid enhancement of synthesis of polyphenylalanine by ribosomal preparations from sensitive Escherichia coli cells.

To prove that the site of the lethal action of streptomycin occurs at a late stage of protein synthesis, one must show that the block of protein synthesis occurs before 
or at the same time as loss of viability, that the block is complete enough to account for loss of viability or other possible intermediate effects, and that the block is irreversible and irreparable when the cells lose their viability.

Some attempts at evaluating the kinetics of the effects of streptomycin on protein synthesis and on survival of viable cells have been made (Hurwitz, Rosano \& Landau, 1962). The effects of the antibiotic on both parameters were found to be complex. The decline in viable count resulting from exposure to streptomycin was preceded by a period during which the viable count remained unchanged. The duration of this period of apparent bacteriostasis was inversely related to the concentration of streptomycin. The effect of streptomycin on protein synthesis likewise appeared to occur in two stages. The first observed effect was a reduction of the initial rate of synthesis which appeared to coincide with the duration of apparent bacteriostasis. The second stage, which seemed to coincide with the beginning of the decline in viability, was observed as a further decrease in the rate of protein synthesis leading to its eventual cessation.

In another study (Hurwitz, Landau \& Doppel, 1962), it was observed that a brief exposure of Escherichia coli to $1 \mu \mathrm{g}$. streptomycin $/ \mathrm{ml}$. caused a delay in onset of growth of survivors plated after the drug was removed. This reaction to a prior exposure indicated the possibility of investigating an early type of lesion not previously described, i.e. a residual effect found after streptomycin was removed.

The slower growing Mycobacterium fortuitum was used in the following experiments because it enabled greater resolution of the sequence of events preceding and occurring during the loss of viability. More accurate comparisons of the kinetics of biological events, following exposure to streptomycin, with the kinetics of the proposed biochemical mechanism of the lethal action of streptomycin could therefore be made.

\section{METHODS}

The culture of Mycobacterium fortuitum was obtained through the courtesy of Dr L. Wayne. It grows in Difco-Dubos broth base predominantly as singly dispersed cells with about $10 \%$ of the units appearing as clumps. Vigorous shaking of the suspension on a Vortex Jr. mixer reduces the incidence of clumps to about $5 \%$. Generation time in the Dubos broth base is slightly less than $3 \mathrm{hr}$.

When plated on Dubos broth base containing $1 \frac{1}{2} \%$ agar, colonies first appear as round, white, dense, discernible dots after $40-48 \mathrm{hr}$ of incubation at $37^{\circ}$. Colony counts were repeated every $\mathbf{2 4} \mathrm{hr}$ until new colonies failed to appear. Appearance of a colony was marked on the bottom of the plate with a coloured felt-tip marker using a different colour for each day's count.

Each experiment was performed with cells growing exponentially in flasks fitted with a Coleman tube sidearm so that nephelometric changes in cell density could also be measured with a Coleman Model 7 Nephelometer.

Special care was taken both with the broth base and with the agar to avoid presence of dust particles and lint which interfered with nephelometric measurement and with recognition of newly emerged colonies on plates.

The bacteria were brought into log phase for each experiment by inoculating flasks containing $20 \mathrm{ml}$. of the broth with about $3 \times 10^{5}$ organisms (estimate based on nephelometric readings of a growing suspension) $16 \mathrm{hr}$ before the start of the 
experiment. At the beginning of the experiment, the suspension contained about $10^{7}$ bacteria $/ \mathrm{ml}$. The cellular suspensions were aerated by rotation on a New Brunswick water bath at $37^{\circ}$.

Protein synthesis was measured as incorporation of ${ }^{14} \mathrm{C}$-leucine into the hot-acid insoluble fraction of the bacteria. Since labelled leucine was incorporated from a non-defined medium, the true specific activity of the incorporated leucine is not known. Comparative results were therefore always obtained within one experiment.

For viable counts the bacteria were diluted in sterile Dubos broth base before plating. The volume after each dilution was kept at $1.0 \mathrm{ml}$. and the suspension was shaken vigorously ( 2 min. on a Vortex Jr. Mixer) before each sampling to ensure maximum dispersion of cells.

\section{RESULTS}

Effects of streptomycin on growth and survival of Mycobacterium fortuitum

Mycobacterium fortuitum, when plated on Dubos broth base agar, first appeared as colonies after $40-48 \mathrm{hr}$ incubation at $37^{\circ}$. Less than $1 \%$ of the colonies took longer than $48 \mathrm{hr}$ to appear. As seen from Fig. 1, a considerable number of colonies failed to appear in $48 \mathrm{hr}$ when exposed to streptomycin, but did appear from the 3rd to the 6th day after plating. Furthermore, as the time of exposure to any lethal concentration of streptomycin increased, the percentage of colonies showing delayed appearance also increased.

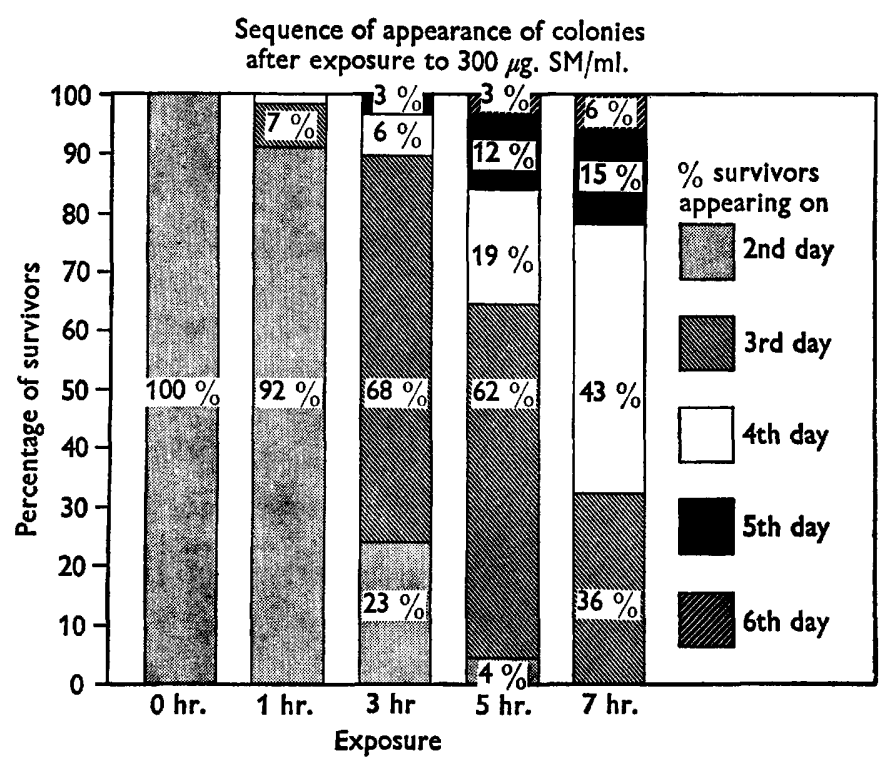

Fig. 1. Delayed appearance of macrocolonies of surviving cells of Mycobacterium fortuitum after exposure to $300 \mu \mathrm{g}$. streptomycin $/ \mathrm{ml}$.

It should be noted that in this illustration the percentage of colonies appearing on any given day is a measure of the percentage of total survivors and not the percentage of the number of bacteria actually plated. Those bacteria which failed to produce macrocolonies, i.e. those rendered non-viable by exposure to streptomycin, represent another parameter which will be described below. 
Once the colony had become visible, its subsequent increase in size was not affected by the length of time it took for the colony to appear. From this it is inferred that the delay in appearance of the colony resulted from a delay in onset of growth and not from a slower growth rate.

The delay in onset of growth was regarded as a form of injury to the cell which could be operationally differentiated from total loss of ability to produce macrocolonies. Those colonies which appeared on the 2 nd day are defined as 'uninjured', those appearing after the 2 nd day as 'injured', and those which fail to appear as 'non-viable'.

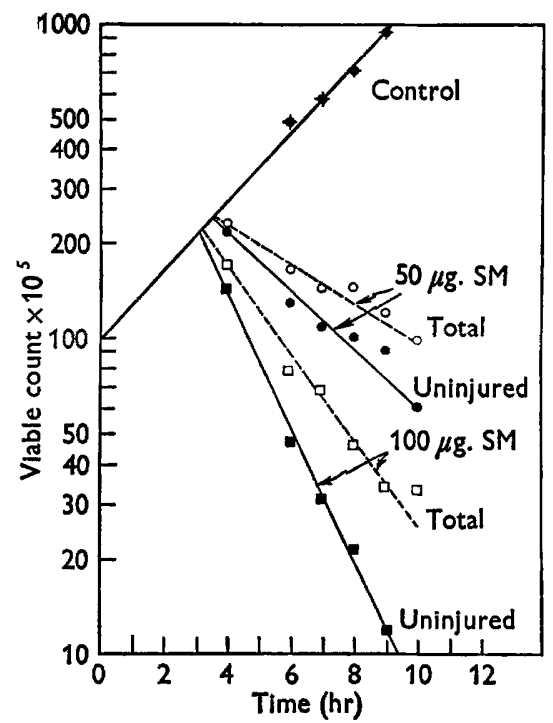

Fig. 2. Kinetics of the decline in total viable count and in number of 'uninjured' cells resulting from exposure of exponentially growing Mycobacterium fortuitum to streptomycin. 'Uninjured' organisms are operationally defined as those producing macrocolonies within $48 \mathrm{hr}$ after being plated.

It should be pointed out, however, that a delay in onset of growth equivalent to the time for several generations might not be detectable by the procedure used, since colonies were counted as early as they could be detected. Under these conditions, it was not possible to precisely regulate the size of the colony at the time of counting, and variations in size of one or more diameters might not be noted. It was therefore possible, indeed likely, that many colonies scored as 'uninjured' may have sustained sufficient injury to delay onset of growth by several hours. One cannot, therefore, rule out the possibility that any exposure to streptomycin may cause some delay in onset of growth and that the measurements herein reported represent only the more easily distinguishable results of relatively severe effects of the drug.

Figure 2 illustrates the effect of exposure to streptomycin on 'injury' and on loss of viability at two concentrations of streptomycin. The dotted lines represent the total number of survivors, while the unbroken lines represent the survival of 'uninjured' cells. At both streptomycin concentrations, the total number of survivors and the number of 'uninjured' cells decreased after a preliminary period 
of increase at the same rate as the control. As time of exposure to streptomycin increased, the extent of injury, as measured by the decrease in the total number of survivors or by the decrease in the number of 'uninjured' cells, also increased. As concentration of streptomycin increased, the decrease in number of survivors began earlier and the extent of injury became greater.

The results show that two effects of streptomycin on sensitive cells could be experimentally differentiated: (1) a sublethal injury from which the cells recover once streptomycin has been removed, and (2) a lethal injury from which no recovery occurred. Studies were therefore undertaken to determine how the kinetics of the block of protein synthesis were related to the kinetics of the sublethal and lethal effects of streptomycin.

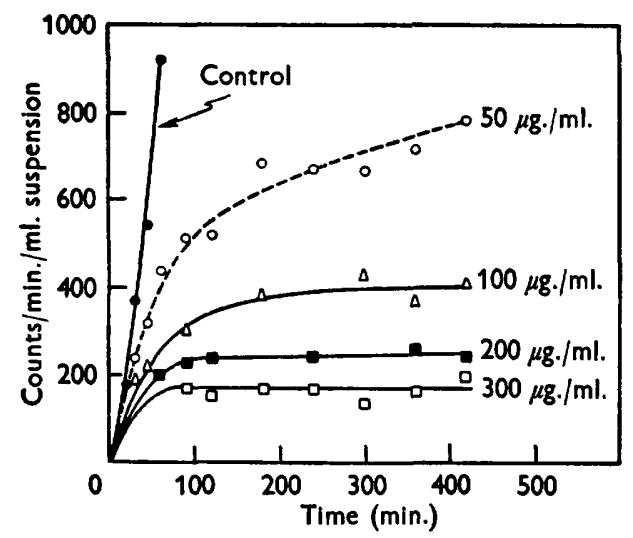

Fig. 3

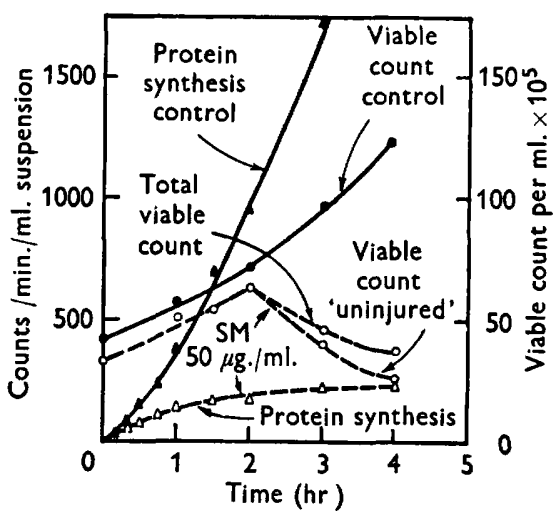

Fig. 4

Fig. 3. Kinetics of the decline in rate of protein synthesis resulting from exposure of exponentially growing Mycobacterium fortuitum to streptomycin. Protein synthesis was measured as the incorporation of ${ }^{14} \mathrm{C}$-leucine into the protein fraction of the bacteria. The numbers at each curve represent the concentration of streptomycin in $\mu \mathrm{g} . / \mathrm{ml}$. The viable count at zero time was $1 \times 10^{7} / \mathrm{ml}$. The medium, Dubos broth base, was supplemented at zero time with $0 \cdot 167 \mu \mathrm{g} .{ }^{14} \mathrm{C}$-leucine/ml., specific activity $0 \cdot 20 \mu \mathrm{C} / \mu \mathrm{g}$.

Fig. 4. Comparative kinetics of the effect of streptomycin on protein synthesis and on viable count of Mycobacterium fortuitum. Streptomycin concentration, $50 \mu \mathrm{g} . / \mathrm{ml}$. Protein synthesis was measured as incorporation of ${ }^{14} \mathrm{C}$-leucine into the protein fraction. 'Uninjured' organisms are operationally defined as those producing macrocolonies within $48 \mathrm{hr}$ after being plated. The medium was supplemented at zero time with $0 \cdot 167 \mu \mathrm{g}$. ${ }^{14} \mathrm{C}$-leucine/ml., specific activity $0 \cdot 20 \mu \mathrm{C} / \mu \mathrm{g}$.

Effects of streptomycin on protein synthesis by Mycobacterium fortuitum. Figure 3 shows the effects of various concentrations of streptomycin on protein synthesis by growing suspensions of Mycobacterium fortuitum. Protein synthesis was markedly inhibited by as little as $50 \mu \mathrm{g} . / \mathrm{ml}$. of the antibiotic.

In Fig. 4 an experiment is illustrated in which the effects of $50 \mu \mathrm{g}$. streptomycin/ $\mathrm{ml}$. on the formation of macrocolonies and on protein synthesis were determined on the same cellular suspension. Although protein synthesis was strongly inhibited after $1 \mathrm{hr}$ of exposure, the viable count at the end of $2 \mathrm{hr}$ had increased at the same rate as the control. A decrease in viable count and the appearance of 'injured' cells were first detected after $3 \mathrm{hr}$ of exposure to streptomycin. 


\section{C. Hurwitz, H. W. Doppel and C. L. Rosano}

Macrocolonies obviously cannot be formed from single cells in the absence of protein synthesis. Since protein synthesis was extensively blocked by $50 \mu \mathrm{g}$. streptomycin $/ \mathrm{ml}$. 1-2 $\mathrm{hr}$ before injury to the cell was detectable by plate counts, some method of recovery of protein-synthesizing ability must be available to the cells after streptomycin is removed. Experiments were therefore performed to determine how much residual protein-synthesizing ability remained after removal of the drug by washing, and whether the early block of protein synthesis could be reversed.

In these experiments, exponentially growing organisms were exposed to $50 \mu \mathrm{g}$. streptomycin $/ \mathrm{ml}$. for varying periods of time. Streptomycin was removed by centrifugation of the suspension at $14,000 \mathrm{rev} . / \mathrm{min}$. for $5 \mathrm{~min}$. and the organisms were resuspended in growth medium containing ${ }^{14} \mathrm{C}$-leucine for further incubation.

The washing procedure itself resulted in from 20 to $50 \%$ loss of viable organisms. $100 \%$ of the organisms could be recovered if the centrifugation was prolonged for 15 min., a time period which would handicap the experiment. Initial experiments using organisms not exposed to streptomycin showed that the decrease in rate of incorporation of ${ }^{14} \mathrm{C}$-leucine into the protein fraction corresponded to the loss of viable organisms resulting from incomplete centrifugation. Similar results were obtained when recovery of viable organisms and protein-synthesizing ability were determined with suspensions which had been minimally exposed to streptomycin (zero time sample). It was therefore concluded that the washing procedure itself had no effect on protein synthesis, per se, and that streptomycin was effectively removed under these conditions.

In the first of the following experiments, the residual protein-synthesizing ability was determined after exposure of the organisms to streptomycin for $1 \mathrm{hr}$ (see Fig. 5). The rate of incorporation of leucine was linear for at least $1 \mathrm{hr}$ after streptomycin was removed and indicated that about $80 \%$ of the protein-synthesizing ability had been lost after $1 \mathrm{hr}$ of exposure to the drug, although the viable count was still increasing at the same rate as the control. Furthermore, it appeared that this loss of protein-synthesizing ability was not immediately reversible on removal of streptomycin.

In later experiments (Fig. 5), exposure to streptomycin was increased to $6 \mathrm{hr}$. The progressive loss in residual protein-synthesizing ability corresponded fairly well with the decrease in rate of incorporation of leucine, observed in Fig. 3, after addition of $50 \mu \mathrm{g}$. streptomycin $/ \mathrm{ml}$. Even after $6 \mathrm{hr}$ of exposure to this concentration of streptomycin some protein-synthesizing ability remained intact.

In the last experiment of this series (Fig. 6), an attempt was made to determine whether the cells could recover their original rate of protein synthesis on prolonged incubation after removal of streptomycin. After exposure to $50 \mu \mathrm{g}$. streptomycin/ $\mathrm{ml}$. for 20,40 and $60 \mathrm{~min}$., the cells were washed free of streptomycin and resuspended in the growth medium supplemented with ${ }^{14} \mathrm{C}$-leucine. Incubation, in the absence of streptomycin, was continued for $5 \mathrm{hr}$ and samples were removed for the determination of the rates of incorporation of label from leucine into the protein fraction. As the duration of the exposure to the drug increased, the initial rate of protein synthesis decreased and it took longer for recovery of protein synthesis to occur. 


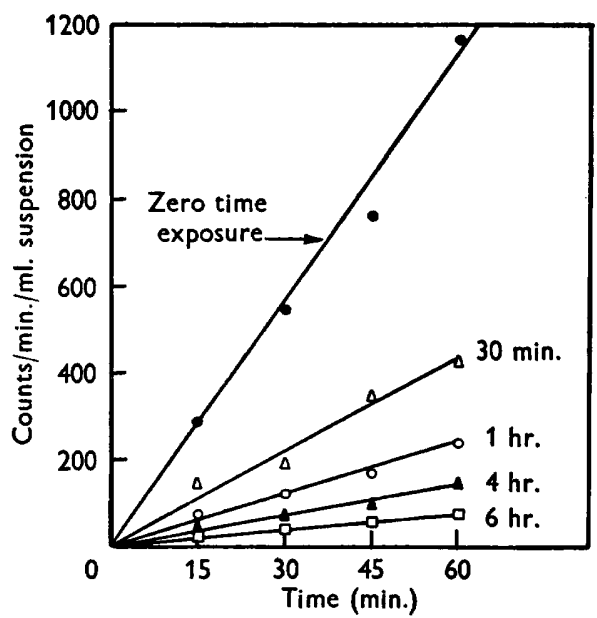

Fig. 5

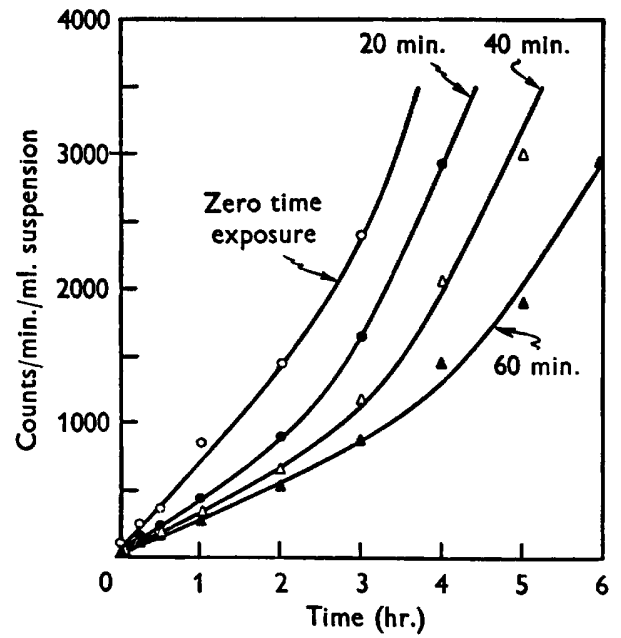

Fig. 6

Fig. 5. Effect of duration of exposure of Mycobacterium fortuitum to $50 \mu \mathrm{g}$. streptomycin/ $\mathrm{ml}$. on the residual rate of incorporation of ${ }^{14} \mathrm{C}$-leucine into the protein fraction. After the indicated exposure, the organisms were washed by centrifugation to remove streptomycin and resuspended in growth medium. The viable count at zero time was adjusted to $1 \times 10^{7}$ viable organisms $/ \mathrm{ml}$, and the medium was supplemented with $0.83 \mu \mathrm{g}$. ${ }^{14} \mathrm{C}$ leucine/ml., specific activity $0 \cdot 14 \mu \mathrm{C} / \mu \mathrm{g}$.

Fig. 6. Kinetics of recovery of protein-synthesizing ability of Mycobacterium fortuitum after incubation following removal of streptomycin. The conditions of the experiment were the same as described in Fig. 5 except that the subsequent incubation after removal of streptomycin was extended to $6 \mathrm{hr}$.

\section{DISCUSSION}

The effects of streptomycin on growth and survival of Mycobacterium fortuitum have been shown to correspond to the effects observed with Escherichia coli (Hurwitz, Rosano \& Landau, 1962) but can be measured with greater resolution. In E. coli, on exposure to streptomycin, an apparent bacteriostasis was followed by a decline in viability. Under different experimental conditions, a delay in onset of growth was observed (Hurwitz, Landau \& Doppel, 1962) which may correspond to the bacteriostasis noted above. All of the above parameters were functions of streptomycin concentration and time of exposure. With $M$. fortuitum, exposure to streptomycin caused a sublethal effect, which could be measured as a delay in onset of growth, and a lethal effect observed as a decline in viability. The extent of both these effects also varied with concentration of streptomycin and with time of exposure.

Streptomycin inhibited protein synthesis in both organisms and the general kinetics of inhibition were similar. With both organisms, there was a decrease in the rate of protein synthesis from the time of addition of the drug, followed by a further decline in rate and eventual stoppage. With Escherichia coli, only the secondary decline in rate seemed to correspond with loss of viability (Hurwitz, Rosano \& Landau, 1962). With Mycobacterium fortuitum, as much as $80 \%$ inhibition of protein synthesis had no apparent effect on the viable count. 
As pointed out earlier, if the lethal action of streptomycin is caused by an inhibition of a late stage of protein synthesis, it must be shown that $(a)$ the block occurs before or at the same time as the decline in viability, $(b)$ that the block is sufficient to account for loss of viability, and $(c)$ that the block is irreversible and irreparable. In addition, as a result of the finding of the sublethal injury described in this report, it must also be shown that the block is early and extensive enough to cause the demonstrated delay in onset of growth, and that it is reparable under conditions where the effect of the drug remains sublethal.

The inhibition of protein synthesis begins very early. In fact, an extensive block in protein synthesis was observed considerably before any effect on the rate of cell division became apparent. This finding raised the question of how cells can divide and eventually produce macrocolonies after their protein-synthesizing capacity has been largely inhibited. Either the inhibition of protein synthesis by streptomycin can be reversed or the lesion can be repaired.

Since an immediate reversal of the block resulting from the removal of streptomycin is ruled out by the experiment reported in Fig. 5, recovery of proteinsynthesizing ability by repair or replacement seems more likely. It should be pointed out, however, that the experiments do not exclude the possibility that recovery of protein synthesis might result from a slow removal of streptomycin from some inhibitory binding site after plating.

As seen in Fig. 5, $80 \%$ of the protein-synthesizing ability of the cells is lost after $1 \mathrm{hr}$ exposure to $50 \mu \mathrm{g}$. streptomycin/ml., yet the rate of cell division is unaffected for at least an additional hour. In addition, no significant delay in onset of growth was observed even after $2 \mathrm{hr}$ of exposure.

The $80 \%$ loss of protein-synthesizing ability after $1 \mathrm{hr}$ of exposure can be looked upon in two ways. Either $80 \%$ of the cells have lost their ability to synthesize protein, while $20 \%$ of the cells have not; or within each cell, on the average, $80 \%$ of its protein-synthesizing ability is destroyed while $20 \%$ remains intact. Recovery of ability to synthesize protein must occur if the cells are to resume their normal growth rate. It seems unlikely that cells which have completely and irreversibly lost their ability to synthesize protein after $1 \mathrm{hr}$ of exposure to streptomycin would be capable of producing macrocolonies after $2 \mathrm{hr}$ of exposure. For this to occur, cells containing no active protein-synthesizing apparatus would have to be able to rapidly synthesize a new apparatus to replace that rendered irreversibly inoperable. If synthesis of a new unblocked apparatus itself involves protein synthesis, as would be the case if ribosome degradation had occurred, it would be difficult to understand recovery of the totally inhibited cells.

On the other hand, if after $1 \mathrm{hr}$ of exposure to streptomycin, $80 \%$ of the proteinsynthesizing ability of each cell is destroyed while $20 \%$ remains intact, rapid recovery of protein synthesis and subsequent growth of each cell would be possible. Conforming to the data in Figs. 5 and 6, the progressive increase in delay of onset of growth might result from the progressive decrease in residual protein-synthesizing ability per cell and the consequent increasing time required for recovery of optimal rate of protein synthesis. Death of a cell or loss of viability would presumably result when insufficient residual protein-synthesizing ability remained to initiate synthesis of a new protein-synthesizing apparatus.

Since the observed effects of streptomycin on protein synthesis seem to adequately 
explain both the delay in onset of growth and the loss of viability, it is concluded that some reaction in a late stage of protein synthesis is the site of bactericidal action of the drug. The occurrence of a block in a stage preceding peptide bond formation (Erdös \& Ullmann, 1959) raises the possibility that exposure to streptomycin may result in an irreversible degradation or alteration of ribosomes in such a way as to prevent their participation in polypeptide formation.

Flaks \& Witting (1963) have recently proposed that streptomycin kills by blocking formation of ribosomes. Our data would indicate that it is more likely that streptomycin promotes degradation or inactivation or ribosomes since the killing occurs too rapidly to result from dilution of the ribosomal content by cell division. When Escherichia coli, growing exponentially in nutrient broth, is exposed to $1 \mu \mathrm{g}$. streptomycin $/ \mathrm{ml}$, more than $90 \%$ of the cells are rendered non-viable within $30 \mathrm{~min}$. (Hurwitz, Rosano \& Landau, 1962). With Mycobacterium fortuitum, under presently described conditions, exposure to $300 \mu \mathrm{g}$. streptomycin $/ \mathrm{ml}$. causes an $80 \%$ loss of viability within $3 \mathrm{hr}$, the time required for one cell division.

This investigation was supported in part by a grant, G 9891, from the National Science Foundation.

This work was presented in part at the 63rd Annual Meeting of the American Society for Microbiology, 5-9 May 1963 (Hurwitz \& Doppel, 1963), Cleveland, Ohio.

\section{REFERENCES}

Erdös, T. \& Ullmann, A. (1959). Effect of streptomycin on the incorporation of amino acids labelled with $\mathbf{C}^{14}$ into RNA and protein in cell-free systems of a Mycobacterium. Nature, Lond. 183, 618.

Flaks, J. G., Cox, E. C. \& WhIte, J. R. (1962). Inhibition of polypeptide synthesis by streptomycin. Biochem. Biophys. Res. Comm. 7, 385.

Flaks, J. G. \& Witting, M. L. (1963). The mode of action of streptomycin. Bact. Proc., p. 118.

Hurwitz, C. \& Doppel, H. W. (1963). Effect of streptomycin on Mycobacterium fortuitum. Bact. Proc., p. 12.

Hurwitz, C., Landau, J. V. \& Doppel, H. W. (1962). Effect of exposure of Escherichia coli to streptomycin on ability to undergo cell division. J. Bact. 84, 1116.

Hurwitz, C. \& Rosano, C. L. (1962). Accumulation of label from $\mathrm{C}^{14}$-streptomycin by Escherichia coli. J. Bact. 83, 1193.

Hurwitz, C., Rosano, C. L. \& Landau, J. V. (1962). Kinetics of loss of viability of Escherichia coli exposed to streptomycin. J. Bact. 83, 1210.

Spotts, C. R. \& Stanier, R. Y. (1961). Mechanism of streptomycin action on bacteria : A unitary hypothesis. Nature, Lond. 192, 633. 